\title{
Strengthening the Character of the Nation of NU Students Through PPKN Learning at International Indonesian Schools
}

\author{
N M Daud ${ }^{1}$, A Masrukhin $^{2}$, H Sriyanto $^{3}$, M N. Willyarto ${ }^{4}$ \\ ${ }^{1}$ Faculty of Business and Management, Universiti Teknologi MARA, Malaysia \\ ${ }^{2}$ Character Building Development Center, Information Systems Department, School of Information Systems, \\ Bina Nusantara University, Jakarta, Indonesia 11480 \\ ${ }^{3}$ Character Building Development Center, Industrial Engineering Department, Faculty of Engineering, Bina \\ Nusantara University, Jakarta, Indonesia 11480 \\ ${ }^{4}$ Language Center, Industrial Engineering Department, Faculty of Humanities, Bina Nusantara University, \\ Jakarta, Indonesia 11480. Research Interest Group Cross-Cultural Communication \\ Banten 15143 \\ *Corresponding author email: agus@binus.ac.id
}

\begin{abstract}
This study aimed to analyse strategies for strengthening the national character through the implementation of PPKn learning and evaluation of character strengthening in PPKn learning. The method used was qualitative with the Indonesian International School as the object of the research. Data was gathered using interview techniques, observation, and documentation. This study resulted in three findings. First, the strategy of strengthening the national character in the PPKn learning planning, namely: (1) identifying the values of religious, nationalist characters (2) analyzing the PPKn material with the issue of nationalism and practice of its values. Second, the strategy of strengthening the national character at the implementation stage of PPKn learning by: (1) strengthening cultural-based nationalism with scouting activities, dancing and cooking Indonesian dishes (2) the love movement for Indonesia. Third, character evaluation was carried out by assessing the morals and attitudes of NU Indonesian students
\end{abstract}

Keywords: character, NU students, PPKN learning

\section{INTRODUCTION}

Globalization not only has a positive impact on people's welfare but also has negative impacts such as selfishness. Therefore, a momentum of national awakening is needed through changes in attitudes and behavior in accordance with the character of the nation. The emergence of phenomena and the emergence of emergency cases of drugs, corruption, disobedience to the rule of law, brawls between students are a reflection of the nation's behavior that is contrary to religious values and Pancasila. Of course, the concern about this condition will lead to the disintegration of the nation. Furthermore, Cogan and Derricot [1] described the increasing global challenges of the $21^{\text {st }}$ century needed attention. Starting from economic disparities, dramatic developments in information technology, conflicts of interest between developing countries, the difficulty of developing mutual belief and goodness, and consumerism will increasingly dominate social life.
Taking into account the condition of such nationstate children, the state takes the initiative to prioritize the development of national character through education, not only depending on parental education but also character education in schools and social communities, where the younger generation carries out social activities. The characters that are built are of course not only religious-based characters, but also related to the development of a sense of nationalism. One of the character education we hope for is to produce the nation's children where their words, attitudes and behavior reflect good character, namely being responsible, caring, prioritizing public interests, and loving peace. The character education process certainly must involve various existing elements, starting from subjects, students, education staff, parents and the community. One of the learning strategies can be through modeling and habituation. For this reason, strengthening the national character is one of the fundamental strategies of education which has a 
fundamental urgency to be implemented immediately at each education level unit. Character education needs a process, examples of exemplary, and habituation or culture in the environment of students, both school and family [2]. One of the goals of character education is to strengthen and develop the values of life that are considered important and necessary so that they become the unique personality / ownership of students as the values developed [3].

This is in line with the current Indonesian government policy through one of the points of Nawacita through the National Movement for the Mental Revolution (GNRM) which was followed up by the Ministry of Education and Culture as the Strengthening Character Education (PPK) program which has been started since 2016. As one of the strategies in driving education character, Strengthening Character Education to further integrate, deepen, expand, and at the same time harmonize the various character education programs and activities that have been implemented [4]. Classroom learning is one of the strategic options in strengthening class-based national character education through a structural approach. curriculum in each subject in the school. One of them is through learning Pancasila and Citizenship Education (PPKn) which has a role as one of the subjects that are so strategic and contribute greatly theoretically and practically in building national insight and strengthening the character of students. Referring to the RI Government Regulation No. 32 of 2013, Citizenship Education is intended to shape students into human beings who have a sense of nationality and love for the country in the context of Pancasila values and morals, constitutional awareness of the 1945 Constitution of the Republic of Indonesia, the values and spirit of nationalism.

NU students who are members of the IPNU / IPPNU organization are a generation who are expected to have a high sense of nationalism. Apart from getting nationalism education at school, they also received education in the IPNU / IPPNU community organizations. As in the inauguration of the new board and the inauguration of students as the management of the special branch of PCI Saudi Arabia at TPA An-Nashiriyah Jeddah, Saudi Arabia. Before being confirmed the male and female students of NU first took part in training in the form of a member loyalty period (Makesta). There are about 100 students aged 12-27 years. The material presented by NU's organization and leadership came from SIJ and SIM [5].
Moral schemes are cognitive structures that provide a way to regulate important aspects of a moral event or ideas, guide thinking about moral issues with thoughts that provide guidance for their behavior [6]. Citizenship education anywhere is basically aimed at forming good citizens (good citizens). What attracts $\mathrm{Nu}$ students in Saudi Arabia is whether they still have a sense of love and nationalism towards their country, where a period of physical and mental growth resided in Saudi Arabia. how is the process of cultivating these characters developing? In order to answer this problem, the researcher tries to understand the strategy of strengthening the national character in PPKn learning planning for NU students in Saudi Arabian schools, namely: first, (1) identifying the value of religious, nationalist character (2) analyzing the PPKn material with the issue of nationalism and the practice of its values. Second, the strategy of strengthening the national character at the implementation stage of PPKn learning by: (1) strengthening cultural-based nationalism with scouting activities, dancing and cooking Indonesian dishes (2) the love movement for Indonesia. Third, character evaluation is carried out by assessing the morals and attitudes of NU Indonesian students.

\section{METHOD}

This study used qualitative methods, while the research subjects were Indonesian students who are studying at the Jeddah Indonesian School (SIJ). This study also used a phenomenology research form of character education through the PPKn subject. Educational theory, Ministry of Education and Culture education curriculum and national perspectif on education concepts were used to reveal the research problem. This study used primary data sources and secondary data. According to Saifuddin [7] that primary data obtained from research subjects in this case were the results of interviews with school residents in Jeddah Indonesian School Saudi Arabia.

According to Sugiyono [8] that primary data sources are data that directly provide data to data collectors, this is the Jeddah Indonesian School (SIJ). While secondary data came from outside the main sources such as books, articles, documents and manuscripts. Garraghan said [9] The final stage is the art of writing, especially in research analysis that uses theories and social science concepts to understand social facts. There were 112 respondents from Jeddah Indonesian School (SIJ), four teachers and six students. Among the informants and respondents who will be used as research partners are teachers, school students and school principals. 
The validity of the data was done in order to obtain valid results and could be scientifically justified. The validity of the data in qualitative research is a systematic examination effort in accordance with certain procedures in skin research consistently.

\section{RESULT AND DISCUSSION}

As one of the strategies in driving character education, Strengthening Character Education to further integrate, deepen, expand, and at the same time harmonize the various character education programs. Classroom learning is one of the strategic options in strengthening class-based national character education through a structural approach. curriculum in each subject in the school. One of them is through learning Pancasila and Citizenship Education (PPKn) which has a role as one of the subjects that are so strategic and contribute greatly theoretically and practically in building national insight and strengthening the character of students. Referring to the RI Government Regulation No. 32 of 2013, Citizenship Education is intended to shape students into human beings who have a sense of nationality and love for the country in the context of Pancasila values and morals, constitutional awareness of the 1945 Constitution of the Republic of Indonesia, the values and spirit of nationalism, including upholding the values of tolerance in diversity. This is in line with Apriani's research findings[10] that schools include the value of appreciation in diversity.

NU students who are members of the IPNU/IPPNU organization are a generation who are expected to have a high sense of nationalism. Apart from getting nationalism education at school, they also received education in the IPNU / IPPNU community organizations. As in the inauguration of the new board and the inauguration of students as the management of the special branch of PCI Saudi Arabia at TPA An-Nashiriyah Jeddah, Saudi Arabia. Before being confirmed the male and female students of NU first took part in training in the form of a member loyalty period (Makesta). There are about 100 students aged 12-27 years. The material presented by NU's organization and leadership came from Jeddah Indonesian School (SIJ) and Mekkah Indonesian School (SIM) [5].

Moral schemes are cognitive structures that provide a way to regulate important aspects of a moral event or ideas, guide thinking about moral issues with thoughts that provide guidance for their behavior. Citizenship education is basically aimed at forming good citizens (good citizens). What attracts $\mathrm{Nu}$ students in Saudi Arabia was whether they still had a sense of love and nationalism towards their country, where a period of physical and mental growth resided in Saudi Arabia. how was the process of cultivating these characters developing? In order to answer this problem, the researcher tried to understand the strategy of strengthening the national character in PPKn learning planning for NU students in Saudi Arabian schools, namely: first, (1) identifying the value of religious, nationalist character (2) analyzing the PPKn material with the issue of nationalism and the practice of its values. Second, the strategy of strengthening the national character at the implementation stage of PPKn learning by: (1) strengthening cultural-based nationalism with scouting activities, dancing and cooking Indonesian dishes (2) the love movement for Indonesia. Third, character evaluation was carried out by assessing the morals and attitudes of NU Indonesian students.

From the results of interviews with IPNU/IPPNU supervisors, Rahma stated that intense national character development through schools. NU student activities were usually centered at the Jeddah Indonesian Mosque. Such as religious and artistic activities, such as training in reading tahlil and marawis. There were two schools of NU students receiving national character education, one Indonesian Jeddah school and the Makkah Indonesian School [11]. PPKn education and identification of character values are expressed by educators as an important first step in a planning strategy to adjust the competence of the national curriculum. So, it is not surprising that schools are given the authority to use curricula in accordance with the culture of the school's vision and mission but still within the Indonesian education system.

The identification of character values according to the teacher still referred to Pancasila as a philosophical source of basic values for the development of national character values which was developed in the PPKn learning planning strategy. Regarding the value of religious character, the teacher viewed that character values that were derived from religiosity, were basic values that need to be strengthened in PPKn learning. In the concept of strengthening character education initiated by the Ministry of Education and Culture [4], religion was the main character value that was emphasized because it comes directly from the existence and linkages of human relationships with God and fellow living beings. Religious character values needed to be strengthened. IPNU and IPPNU students developed the main religious 
character either through PPKn lessons or through NU organizational activities. Referring to the results of interviews with 112 students, $49.1 \%$ strongly agree that they are not happy if there is a religious conflict in Indonesia. They were very sad when there is a conflict between religions. This gave an indication that IPNU and IPPNU students who study in Jeddah had a love of peace between religions, tolerance and non-violence. The existence of religious character values in PPKn learning could provide reinforcement to the character of students in considering global character values that seemed oppose and not in accordance with religious norms.

According to Nunu Nurfirdaus in Koko Adya Winata [12], "Habits are manifested in real behavior such as greeting, smiling, or unreal such as thinking, feeling and behaving. Attitudes and habits in everyday life, such as in social relationships and following rules. Related to the nationalist character. The values of nationalistic characters that are strengthened in the PPKn learning include love for the country, the spirit of the nation, obeying the law, discipline, integrity, achievement, respect for differences. Strengthening the value of nationalistic characters carried out by teachers in PPKn learning planning is a step that is in line with the mission of PPKn as nationalism education. According to Maftuh [13], the mission of Citizenship Education is nationalism education. Through Citizenship Education it was hoped that the sense of the nation or students' nationalism could be fostered, so that they love, feel the nation more, and are willing to sacrifice for their nation and country. IPNU and IPPNU students who went to school in Jeddah loved Indonesian's products. Of the 112 students who gave answers, there were 64 students who loved domestic products or $57.1 \%$. Related to pride as an Indonesian citizen who has many cultures. 75 students or $67 \%$ are very proud to be Indonesian citizens.

The PPKn subject itself is felt by the students to increase students' understanding of love for the country. As many as 105 students agreed that if the PPKn material added to an attitude of nationalism, only seven people were neutral. These seven people were neutral or do not agree if the PPKn lesson adds to the attitude of nationalism. The development of character values was none other than an initiation by the principal assisted by teachers, to be developed in the vision and mission of the Indonesian School of Makkah and the Indonesian School of Jeddah, namely producing excellent graduates, being able to compete at national and international levels and developing the values of the nation's cultural character entrepreneurial spirit, and anti-corruption. Strengthening nationalism based on culture through the national anthem and national compulsory anthem. The strategy of strengthening the value of the nationalist character is carried out through a cultural approach by reading the Pancasila text and national obligatory songs. Another character development strategy was through a cultural approach such as singing the national anthem "Indonesia Raya" at a flag ceremony. The activity of singing the national anthem was used as one of the strategies to strengthen the value of the nationalist character which is held in each preliminary PPKn learning activity. Based on data processing on the participants, it showed that out of 122 students 16 students or $14.3 \%$ of them were enthusiast about exploring dance. $10.7 \%$ are active in paskibra, $7.1 \%$ of students took extracurricular silat and the most of them were participating in scouting activities up to $62.5 \%$. From the findings, it could be explained that Indonesian culture has always been and continues to be done by students in Saudi Arabia.

The totality of values includes character, character, character and other psychic traits [14] From the research results it could be understood that strategies in order to strengthen the character of the nation in facing the era of globalization, using a learning approach that refers to the principles of the 2013 curriculum namely scientific approach and extracurricular activities. These results showed a positive side of student character. This could be proven by looking at the results of indepth interviews with participants and resource persons. PPKn lessons were very important for NU students because they help students understand Indonesian culture and citizenship. This was approved by all Indonesian Jeddah school students $(100 \%)$. However, as an evaluation for schools and to be improved, namely related to PPKn education, it appeared that those who were neutral or disagree with the PPKn material were easy to understand, there were 47 students out of 112 student respondents or $42 \%$, almost half of the students find it difficult to understand the PPKn material. This was in line with the questionnaire question that learning activities in PPKn subjects were quite interesting and not boring, it seemed that $30.4 \%$ or 30 students did not agree that the PPKn material was interesting. This could be the following research material whether this problem is due to the PPKn material factor or the unattractive teaching 
method. PPKn learning methods should be improved, such as discovery learning and problembased learning with discussion and presentation strategies can be interesting because there is twoway communication between students and teachers. Moreover, through this learning activities, it is expected that students have skills such as critical thinking skills, creative thinking, communication skills, and collaborative learning[4]. however, if we pay attention to the research of Sriyanto and Masrukhin which was published in the IOP journal publication [15] that the main factor of learning is not the material and methods of the teacher but the students.

\section{CONCLUSION}

Based on the data analysis, it could be concluded. Firstly, the value of the nationalist religious character of NU students in Saudi Arabia was very good, and seemed that they were sad if there was a religious conflict. In addition, they were very tolerant and open to differences in religious culture. the PPKn learning method. From the results of the primary data analysis, they were less interested in PPKn material. Secondly, related to the strategy of strengthening the character of the nation through PPKn learning as a culture-based strengthening of nationalism with scouting, dancing and cooking Indonesian dishes, especially scout activities were actively participated by the majority of NU students.

\section{ACKNOWLEDGMENTS}

"This work is supported by Research and Technology Transfer Office, Bina Nusantara University as a part of Bina Nusantara University's International Research Grant entitled Strengthening the Character of the Nation of NU Students through PPKn Learning at International Indonesian Schools in Saudi Arabia with contract number: No.026/VR.RTT/IV/2020 and contract date: 6 April 2020".

\section{REFERENCES}

[1] R. Cogan, J., Derricott, R., \& Derricott, Citizenship for the 21st century: An international perspective on education. London, 1998.

[2] S. A. Nugraha, "Konsep Dasar Pendidikan
Karakter," Al-Munawwarah J. Pendidik. Islam., vol. 8, no. 2, p. 87, 2016.

[3] R. Putry, "Nilai Pendidikan Karakter Anak di Sekolah Perspektif Kemendiknas, Gender Equality," Int. J. Child Gend. Stud., vol. 4, no. 1, 2018.

[4] Kementerian Pendidikan dan Budaya, Konsep dan pedoman penguatan pendidikan karakter. Jakarta: Tim PPK Kemendikbud, 2016.

[5] NU, “'ipnu-dan ippnu-arab-saudi-resmidibentuk," 2020. Accessed: Nov. 16, 2020. [Online]. Available: https://www.nu.id/post/read/92679/ipnudan ippnu-arab-saudi-resmi-dibentuk.

[6] A. Hasanah, Pendidikan Karakter Berperspektif Islam. Bandung: Insan Komunika, 2013.

[7] Saifuddin, Metode Penelitian. Yogjakarta: pustaka Pelajar, 1997.

[8] Sugiono, Research Methods, Quantitative, Qualitative, and $R \& D$. Bandung: Alfa Beta, 2017.

[9] W. Hernawan, "Islamic unity:background and development. dissertation," p. 3, 2018.

[10] A.-N. Apriani and Y. D. Ariyani, "Implementasi Pendidikan Nilai Nasionalisme Dalam Pembelajaran Living Values," LITERASI (Jurnal Ilmu Pendidikan), 2017, doi: 10.21927/literasi.2017.8(1).59-73.

[11] Rahma, interview. 2020.

[12] D. Winata, Koko Adya Landasan, "Teori Pendidikan Karakter Di Sekolah (Tinjauan Ontologi, Epistimologi Dan Aksiologi)," J. Al-Amar, vol. 1, no. 3, 2020.

[13] M. B, "Internalisasi Nilai-Nilai Pancasila Dan Nasionalisme Melalui Pendidikan Kewarganegaraan," J. Educ., vol. 2, pp. 134-144, 2008.

[14] A. Madjid, Pendidikan Karakter Perspektif Islam. Bandung: Rosdakarya, 2011.

[15] H. Sriyanto and A. Masrukhin, "The role of module quality, learning methods, and lecturers with student learning outcomes: Model multiple regression \{SPSS\} approach," J. Phys. Conf. Ser., vol. 1402, p. 22066, Dec. 2019, doi: 10.1088/1742-6596/1402/2/022066. 